\title{
Nitrate uptake of the red tide dinoflagellate Prorocentrum micans measured using a nutrient repletion method: effect of light intensity
}

\author{
Kyung Ha Lee ${ }^{1}$, Hae Jin Jeong ${ }^{1,2, *}$, Hye Jeong Kim ${ }^{1}$ and An Suk Lim ${ }^{1}$ \\ ${ }^{1}$ School of Earth and Environmental Sciences, College of Natural Sciences, Seoul National University, Seoul 08826, Korea \\ ${ }^{2}$ Advanced Institutes of Convergence Technology, Suwon 16229, Korea
}

The ability of a red tide species to take up nutrients is a critical factor affecting its red tide dynamics and species competition. Nutrient uptake by red tide species has been conventionally measured by incubating nutrient-depleted cells for a short period at 1 or 2 light intensities. This method may be applicable to certain conditions under which cells remain in oligotrophic water for a long time and high nutrients are suddenly introduced. Thus, a new method should be developed that can be applicable to the conditions under which cells are maintained in eutrophicated waters in healthy conditions and experience light and dark cycles and different light intensities during vertical migration. In this study, a new repletion method reflecting these conditions was developed. The nitrate uptake rates of the red tide dinoflagellate Prorocentrum micans originally maintained in nitrate repletion and depletion conditions as a function of nitrate concentration were measured. With increasing light intensity from 10 to $100 \mu \mathrm{E} \mathrm{m}^{-2} \mathrm{~s}^{-1}$, the maximum nitrate uptake rate $\left(\mathrm{V}_{\max }\right)$ of P. micans increased from 3.6 to $10.8 \mathrm{pM}$ cell $^{-1} \mathrm{~d}^{-1}$ and the half saturation constant $\left(\mathrm{K}_{\mathrm{s}-\mathrm{NO} 3}\right)$ increased from 4.1 to $6.9 \mu \mathrm{M}$. At $20 \mu \mathrm{E} \mathrm{m} \mathrm{m}^{-2} \mathrm{~s}^{-1}$, the $\mathrm{V}_{\max }$ and $\mathrm{K}_{\mathrm{s}-\mathrm{NO} 3}$ of P. micans originally maintained in a nitrate repletion condition were similar to those maintained in a nitrate depletion condition. Thus, differences in cells under nutrient repletion and depletion conditions may not affect $\mathrm{K}_{\mathrm{s}-\mathrm{NO3}}$ and $\mathrm{V}_{\max }$. Moreover, different light intensities may cause differences in the nitrate uptake of migratory phototrophic dinoflagellates.

Key Words: dinoflagellate; half saturation constant; harmful algal bloom; nitrate; nutrient; red tide; uptake rate

\section{INTRODUCTION}

Red tides or harmful algal blooms, discolorations of the sea surface due to plankton blooms, sometimes cause large-scale mortalities of fish and shellfish (Glibert et al. 2014, Hu et al. 2014, Jeong et al. 2015, Lee et al. 2016). Furthermore, they cause great losses to the aquaculture and tourism industries of many countries (Anderson et al. 2012, Fu et al. 2012, Park et al. 2013b). Therefore, minimizing losses due to red tides is a critical concern to people in the aquaculture industry, scientists, and government officials. To minimize the losses, it is necessary to understand and predict the outbreak and spread processes of red tides caused by certain red tide causative species.

Phototrophic diatoms, flagellates, and dinoflagellates are the major red tide causative species, and they compete strongly with each other (Anderson et al. 2002, Glibert et al. 2012, Jeong et al. 2013, Lim et al. 2014). Furthermore, many species within each major group also compete with each other. In these competitions, the relative nutrient
(9) \$ This is an Open Access article distributed under the terms of the Creative Commons Attribution Non-Commercial License (http://creativecommons.org/licenses/by-nc/3.0/) which permits unrestricted non-commercial use, distribution, and reproduction in any medium, provided the original work is properly cited.
Received March 5, 2017, Accepted May 20, 2017

*Corresponding Author

E-mail: hjjeong@snu.ac.kr

Tel: +82-2-880-6746, Fax: +82-2-874-9695 
acquisition and growth rates are very important parameters. In general, diatoms grow faster by taking up nutrients at lower nutrient concentrations than flagellates or dinoflagellates having similar volumes (Jeong et al. 2015). However, flagellates and dinoflagellates outcompete diatoms by growing under low nutrient conditions through conducting mixotrophy (i.e., feeding on prey) or vertical migration between well-lit oligotrophic surface water and dim-lit eutrophicated deep water (Smayda 1997, Ji and Franks 2007, Jeong et al. 2015). Therefore, there have been many efforts to obtain data on the nutrient uptake and growth rates of red tide species. However, so far, among the $\sim 300$ reported red tide species, the nutrient uptake of only 20-30 species has been reported (Smayda 1997, Kudela et al. 2010, Jeong et al. 2015). In particular, data on the nutrient uptake rates, nutrient half saturation constant, or growth rates of many major red tide organisms are still lacking (Jeong et al. 2015).

Eppley and Coatsworth (1968) first measured the nutrient uptake rate of microalgae; they measured the nitrate uptake of the diatom Ditylum brightwellii after incubating nitrate depleted cells for 2-3 h. Later, many studies measuring the nutrient uptake (i.e., uptake of nitrate, nitrite, ammonia, and phosphate) of red tide species used this method or partially modified methods in which nutrient depleted cells were incubated for a short period (usually $<3 \mathrm{~h}$ ). There are 2 major methods of rendering the nutrient concentration in the stock of a target red tide species negligible: 1) wait until cells in a culture utilize all nutrients; and 2) harvest cells growing in nutrient repletion conditions and wash them several times with nutrient-free medium (Cochlan and Harrison 1991, Qi and Zhu 1994, Lomas and Glibert 2000, Fan et al. 2003, Herndon and Cochlan 2007, Sinclair et al. 2009, Hu et al. 2014, Killberg-Thoreson et al. 2014). However, these methods render cells unhealthy and require that nutrient concentrations in the stock be measured several times to make sure that the concentrations are negligible. Indeed, these conventional methods may be applied to certain conditions under which cells stay in oligotrophic water for a long time and high nutrients are suddenly introduced. Furthermore, these conventional methods do not reflect the fact that red tide species experience a light-dark cycle and most flagellates and dinoflagellates experience different light intensities during diel vertical migration (Jeong et al. 2015). Thus, a new method should be developed that can be applied to the conditions under which cells are maintained in eutrophicated waters in healthy conditions and experience a light and dark cycle and dif- ferent light intensities during diurnal vertical migration.

In this study, a new repletion method reflecting these conditions that many red tide cells experience was developed. In this nutrient repletion method, 1) cells growing exponentially in nutrient repletion conditions were used; 2) two different initial nutrient concentrations (i.e., high and medium concentrations) were provided to cover a wide range of nutrient concentrations; 3 ) a light and dark cycle was established to reflect the biological clock; 4) cell abundance and nutrient concentrations were measured on a daily basis for 5-10 d; 5) the daily uptake rate of a red tide species was calculated using the differences in cell abundance and nutrient concentrations at a daily interval; 6) daily uptake rates were plotted as a function of the nutrient concentration after discounting rates in acclimating periods and when they dropped below a certain level; 7) the maximum uptake rate and half saturation constant were obtained using Michaelis-Menten equations.

This study used this new method to measure the nitrate uptake of Prorocentrum micans, which is one of the most frequent red tide forming species in the coastal waters of many countries (Uchida 1981, Shumway 1990, Zheng-fang et al. 1995, Peña-Manjarrez et al. 2005, Park et al. 2013a). To compare the effects of the maintenance conditions of cells, the nitrate uptake of $P$. micans originally maintained in nitrate depletion conditions was also measured by incubating cells for $>6 \mathrm{~d}$ in a light and dark cycle. These results were also compared with the results of Qi and Zhu (1994) in which the nitrate uptake of P. micans was measured by using cells in nitrate depletion conditions for a short period without a light and dark cycle.

Many phototrophic dinoflagellates, including P. micans, experience wide ranges of light intensities because they conduct diel vertical migration (Jeong et al. 2015). Thus, the effects of light intensity on the nutrient uptake of a red tide species should be explored. Therefore, the nitrate uptake of $P$. micans was measured under 6 different light intensities of $0-200 \mu \mathrm{E} \mathrm{m}^{-2} \mathrm{~s}^{-1}$ (i.e., $0,10,20,50,100$, and $200 \mu \mathrm{E} \mathrm{m}^{-2} \mathrm{~s}^{-1}$ ).

Nutrient concentration and light intensity are 2 of the most critical factors affecting photosynthesis and, in turn, the growth of phototrophic red tide organisms. Thus, the results of this study provide a basis for understanding the nitrate kinetics of red tide dinoflagellates and light effects and eventually red tide dynamics. Moreover, this study provides a new method of easily measuring the nitrate uptake of phytoplankton using healthy cells. 


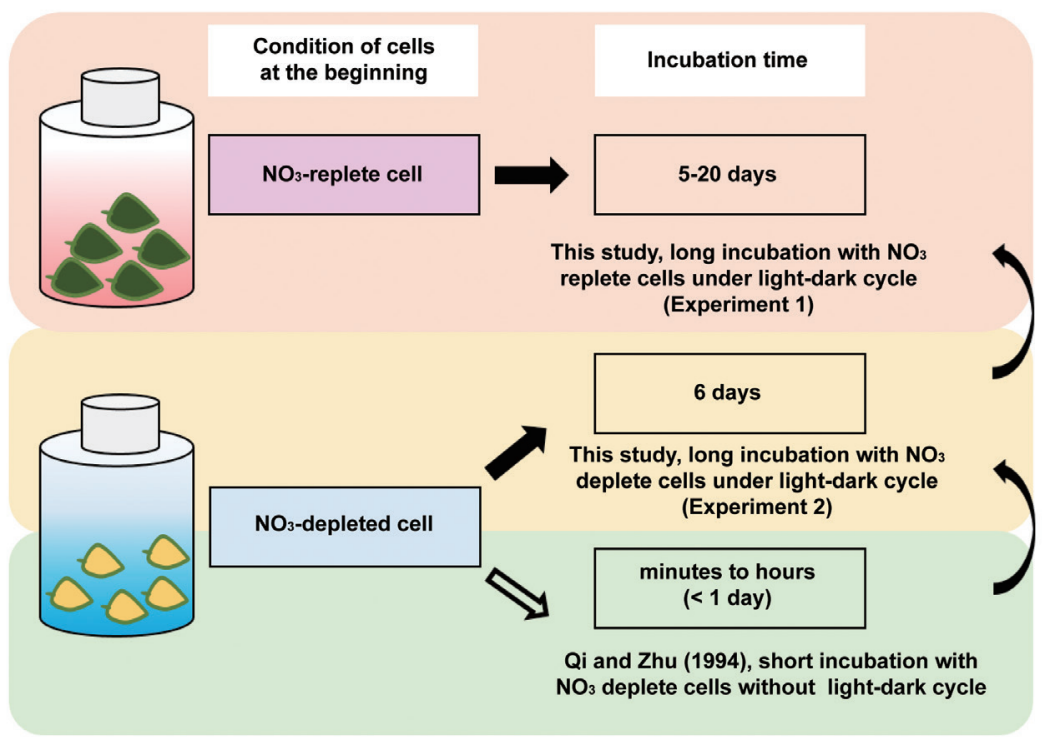

Fig. 1. Diagram of the 3 different methods of measuring nitrate $\left(\mathrm{NO}_{3}\right)$ uptake rates. The $\mathrm{NO}_{3}$ conditions of cells at the beginning of the experiments, acclimation period, and incubation time were compared. Closed arrows and open arrow indicate this study and Qi and Zhu (1994), respecetively.

\section{MATERIALS AND METHODS}

\section{Preparation of experimental organisms}

P. micans used in this study was originally isolated from a plankton water sample collected from Shiwha Bay, Korea, in October 2009. Phototrophic cells were grown in enriched f/2-Si seawater media (Guillard and Ryther 1962, Guillard 1975) at $20^{\circ} \mathrm{C}$ under an illumination of 20 $\mu \mathrm{E} \mathrm{m} \mathrm{m}^{-2} \mathrm{~s}^{-1}$ of cool white fluorescent light on a $14: 10 \mathrm{~h}$ light-dark cycle.

\section{Nitrate uptake as a function of nitrate concen- trations under different light intensities using the $\mathrm{N}$ repletion method}

Experiment 1 was designed to investigate the nitrate uptake of P. micans as a function of nitrate concentration at each of the 6 different light intensities when cells were originally maintained under nitrate $\left(\mathrm{NO}_{3}\right)$ repletion conditions (Table 1, Fig. 1).

Dense cultures of $P$. micans growing photosynthetically in $\mathrm{f} / 2$-Si medium were transferred to 1-L polycarbonate (PC) bottles and the bottles were placed on a shelf in a culture room at $20^{\circ} \mathrm{C}$ under a $14: 10 \mathrm{~h}$ light : dark cycle and acclimated at the target light intensity for $4 \mathrm{~d}$. Three

Table 1. Experimental design and comparison of the 3 different methods of measuring the nitrate $\left(\mathrm{NO}_{3}\right)$ uptake of Prorocentrum micans

\begin{tabular}{|c|c|c|c|c|c|c|}
\hline Method & $\begin{array}{c}\text { Initial cells } \\
\text { condition }\end{array}$ & $\begin{array}{c}\mathrm{T} \\
\left({ }^{\circ} \mathrm{C}\right) \\
\end{array}$ & $\begin{array}{c}\mathrm{LI} \\
\left(\mu \mathrm{E} \mathrm{m}^{-2} \mathrm{~s}^{-1}\right)\end{array}$ & $\begin{array}{c}\text { Measured } \\
\text { component }\end{array}$ & $\begin{array}{l}\text { HNC } \\
(\mu \mathrm{M})\end{array}$ & IT \\
\hline $\begin{array}{l}\text { Experiment 1: long incubation } \\
\text { with } \mathrm{NO}_{3} \text { replete cells under } \\
\text { light-dark cycle }\end{array}$ & $\mathrm{N}$ replete & 20 & $\begin{array}{c}0,10,20,50 \\
100,200\end{array}$ & $\mathrm{~V}_{\max }, \mathrm{K}_{\mathrm{s}-\mathrm{NO} 3}, \mathrm{MGR}$ & $120-130$ & $1-3 \mathrm{wk}$ \\
\hline $\begin{array}{l}\text { Experiment 2: long incubation } \\
\text { with } \mathrm{NO}_{3} \text { deplete cells under } \\
\text { light-dark cycle }\end{array}$ & $\mathrm{N}$ deplete & 20 & 20 & $\mathrm{~V}_{\max }, \mathrm{K}_{\mathrm{s}-\mathrm{NO}}$ & 100 & $6 \mathrm{~d}$ \\
\hline $\begin{array}{l}\text { Qi and Zhu (1994): short } \\
\text { incubation with } \mathrm{NO}_{3} \text { deplete } \\
\text { cells without light-dark cycle }\end{array}$ & $\mathrm{N}$ deplete & 20 & $56-63$ & $\mathrm{~V}_{\max }, \mathrm{K}_{\mathrm{s}-\mathrm{NO}}$ & 10 & Likely short ${ }^{2}$ \\
\hline
\end{tabular}

$\mathrm{T}$, temperature; $\mathrm{LI}$, light intensity; $\mathrm{HNC}$, highest $\mathrm{NO}_{3}$ concentration tested; IT, incubation time; $\mathrm{V}_{\text {max }}$, the maximum uptake rate; $\mathrm{K}_{\mathrm{s}-\mathrm{NO} \text {, }}$, half saturation constant; MGR, the maximum growth rate.

${ }^{a}$ Qi and Zhu (1994) did not provide information on incubation time, light : dark cycle, and initial cell abundance and only indicated that they used a method similar to Eppley (1973), in which the incubation time was short. 
1-mL aliquots were subsampled and then cells were enumerated to determine the cell concentration.

P. micans cells were added to triplicate $800 \mathrm{~mL}$ culture flasks by transferring predetermined volumes of cultures (final cell concentration $=\sim 1,000$ cells $\mathrm{mL}^{-1}$, but $\sim 500$ cells $\mathrm{mL}^{-1}$ for $200 \mu \mathrm{E} \mathrm{m}^{-2} \mathrm{~s}^{-1}$ and medium initial nutrient concentrations) (Table 1). A stock solution of nitrate made based on the $\mathrm{f} / 2$-Si medium concentration was added to the 2 different final concentrations $\left(\mathrm{NO}_{3}=20-30 \mu \mathrm{M}\right.$ for medium initial concentrations and 100-130 $\mu \mathrm{M}$ for high initial concentrations) (Table 1). A sufficient amount of stock solution of phosphate $\left(\mathrm{PO}_{4}\right)$ also prepared based on the $\mathrm{f} / 2$-Si medium concentration was added so that it would not be limiting before $\mathrm{NO}_{3}$ was limiting. Trace metals and vitamins were also added plentifully with consideration of the ratio of nitrate to each chemical in an $\mathrm{f} / 2$-Si medium.

The flasks were placed on shelves in 3 temperaturecontrolled culture rooms. By adjusting distances between light source and flasks, target light intensities of 0 (complete darkness), 10, 20, 50, 100, and $200 \mu \mathrm{E} \mathrm{m}^{-2} \mathrm{~s}^{-1}$ were established (Table 1). Triplicate culture flasks for target light intensity (14:10 h light : dark cycle) were incubated at $20^{\circ} \mathrm{C}$. The duration of the incubation was ca. 1 week for medium nitrate concentrations $(20-30 \mu \mathrm{M})$, but 2-3 weeks for higher concentrations (100-130 $\mu \mathrm{M})$ (Table 1).

Twenty-mL aliquots were subsampled from each flask every day, and 6-mL aliquots were used for the determination of cell concentration and 14-mL aliquots for the determination of nutrient concentrations.

Cell concentration was determined by enumerating cells on three 1-mL Sedgwick-Rafter counting chambers. Fourteen-mL aliquots were filtered through GF/F filters and then concentrations of nitrate (actually nitrate + nitrite in the Cd-coil reduction method) and phosphate were measured using a nutrient analyzer (QuAAtro; Seal Analytical, Norderstedt, Germany).

\section{Nitrate uptake using the $\mathrm{N}$ depletion method}

Experiment 2 was designed to investigate the nitrate uptake of $P$. micans at a single light intensity by cells originally maintained under nitrate depletion conditions (Table 1, Fig. 1).

Cells in a dense culture of $P$. micans growing photosynthetically in $\mathrm{f} / 2$-Si medium were concentrated using a 20 $\mu \mathrm{m}$ mesh filter after nitrate was depleted and immediately transferred to 1-L PC bottles containing oligotrophic oceanic waters $\left(\mathrm{NO}_{3}\right.$ concentration $=0.67 \mu \mathrm{M}, \mathrm{PO}_{4}=0.12$ $\mu \mathrm{M})$. The bottles were placed on a shelf in a culture room at $20^{\circ} \mathrm{C}$ under a $14: 10 \mathrm{~h}$ light : dark cycle and then maintained for $9 \mathrm{~d}$. The final concentration of nitrate was 0.35 $\mu \mathrm{M}$. Three 1-mL aliquots were subsampled and then cells were enumerated to determine the cell concentration.

$P$. micans cells were added to triplicate $250-\mathrm{mL}$ culture flasks by transferring predetermined volumes of cultures (final concentration $=\sim 1,000$ cells $\mathrm{mL}^{-1}$ ). A stock solution of $\mathrm{NO}_{3}$ based on $\mathrm{f} / 2$-Si medium concentrations was added to the 7 different final concentrations $(1,2.5,5,10,25$, 50 , and $100 \mu \mathrm{M}$ ) (Table 1). Stock solutions of $\mathrm{PO}_{4}$, trace metals, and vitamins based on the f/2-Si medium were added sufficiently so as to not be limiting.

The flasks were placed on shelves in a temperaturecontrolled culture room at $20^{\circ} \mathrm{C}$ at $20 \mu \mathrm{E} \mathrm{m}^{-2} \mathrm{~s}^{-1}$ with a 14 : $10 \mathrm{~h}$ light : dark cycle (Table 1). Triplicate culture flasks were also set up. The duration of the incubation was $6 \mathrm{~d}$.

Fifteen-mL aliquots were subsampled from each flask every day and 5- $\mathrm{mL}$ aliquots were used for the determination of cell concentration and 10-mL aliquots for the determination of nutrient concentrations. Cell and nitrate concentrations were determined as described above.

\section{Calculation of nitrate uptake rates and half satu- ration constant in the $\mathrm{N}$ repletion method}

In experiment 1 , the nitrate uptake rate of a P. micans cell was determined by dividing the reduction in nitrate concentration $(\mathrm{N})$ by the mean cell concentration at 1 or $2 \mathrm{~d}$ intervals;

$$
\begin{aligned}
& \text { Reduction in the nutrient concentration } \\
& \text { in a day }\left(\mu \mathrm{M} \mathrm{d}^{-1}\right)=\left(\mathrm{N}_{\mathrm{t} 2}-\mathrm{N}_{\mathrm{t} 1}\right) /\left(\mathrm{t}_{2}-\mathrm{t}_{1}\right)
\end{aligned}
$$

, where $t_{2}-t_{1}=1 d$, but $2 d$ for the high nitrate concentration at $10 \mu \mathrm{E} \mathrm{m}^{-2} \mathrm{~s}^{-1}$.

$$
\begin{aligned}
& \text { Mean cell concentration (cells } \left.\mathrm{mL}^{-1}\right)= \\
& {\left[\mathrm{Ct}_{2}-\mathrm{Ct}_{1}\right] /\left[\ln \left(\mathrm{Ct}_{2} / \mathrm{Ct}_{1}\right)\right]}
\end{aligned}
$$

, where $t_{2}-t_{1}=1 d$, but $2 d$ for the high nitrate concentration at $10 \mu \mathrm{E} \mathrm{m}^{-2} \mathrm{~s}^{-1}$.

Day 0 to 1 or day 2 were treated as the acclimation period, and thus data from these days were not used in calculation. Data on daily nitrate uptake rates from day 2 or 3 to the day before the growth rate of $P$. micans exceeded half the maximum growth rate in each experiment were plotted by the Michaelis-Menten equation;

$$
\mathrm{V}=\mathrm{V}_{\text {max }}\left[\mathrm{N}^{*} /\left(\mathrm{K}_{\mathrm{s}-\mathrm{NO} 3}+\mathrm{N}^{*}\right)\right]
$$

, where $\mathrm{V}_{\max }=$ maximum uptake rate $\left(\mathrm{pM}\right.$ cell $\left.^{-1} \mathrm{~d}^{-1}\right), \mathrm{N}^{*}=$ mean nitrate concentration $(\mu \mathrm{M})$, and $\mathrm{K}_{\mathrm{s}-\mathrm{NO} O 3}$ = half saturation constant for nitrate uptake $(\mu \mathrm{M})$. 
Mean nitrate concentration $(\mu \mathrm{M})=$

$\left[\mathrm{N}_{\mathrm{t} 2}-\mathrm{N}_{\mathrm{t} 1}\right] /\left[\ln \left(\mathrm{N}_{\mathrm{t} 2} / \mathrm{N}_{\mathrm{t} 1}\right)\right]$

, where $\mathrm{N}=$ nitrate concentration at a single day, $\mathrm{t}_{2}-\mathrm{t}_{1}=1$ $\mathrm{d}$, but $2 \mathrm{~d}$ for the high nitrate concentration at $10 \mu \mathrm{E} \mathrm{m}^{-2}$ $\mathrm{s}^{-1}$.

The specific growth rate of $P$. micans $\left(\mu, \mathrm{d}^{-1}\right)$ was calculated as:

$$
\mu=\left[\ln \left(\mathrm{Ct}_{2} / \mathrm{Ct}_{1}\right)\right] /\left(\mathrm{t}_{2}-\mathrm{t}_{1}\right)
$$

The maximum growth rate $\left(\mu_{\max }\right)$ of P. micans was obtained after data were fitted to a Michaelis-Menten equation:

$$
\mu=\mu_{\max }\left[\mathrm{N}^{*} /\left(\mathrm{K}_{\mathrm{GR}}+\mathrm{N}^{*}\right)\right]
$$

, where $\mathrm{N}^{*}=$ mean nitrate concentration $(\mu \mathrm{M}), \mathrm{K}_{\mathrm{GR}}=$ the nutrient concentration sustaining $1 / 2 \mu_{\max }$.

Data were iteratively fitted to the model using DeltaGraph (SPSS Inc., Chicago, IL, USA), and statistical analyses were conducted using IBM SPSS Statistics version 21 (IBM Corp., Armonk, NY, USA).

\section{Calculation of nitrate uptake rates and half satu- ration constant in the $\mathrm{N}$ depletion method}

In experiment 2, the nitrate uptake rate of a $P$. micans cell was also determined by dividing the reduction in nitrate concentration $(\mathrm{N})$ by the mean cell concentration at $1 \mathrm{~d}$ intervals; the reduction in the nitrate concentration, mean nitrate concentration, and mean cell concentration were obtained using Eqs. (1), (2), and (3), respectively.

Day 0 to 1 was treated as an acclimation period, and thus data obtained in this period were not used. The data on daily nitrate uptake rates from day 1 or 3 were plotted to Eq. (3) and (4) as the repletion method and iteratively fitted to the model using DeltaGraph (SPSS Inc.).

\section{RESULTS}

\section{Daily variations in nitrate and cell concentra- tions and growth rate in the $\mathrm{N}$ repletion method}

In experiment 1, with increasing elapsed incubation time, the P. micans concentration increased and then became saturated, while the nitrate concentration rapidly decreased and then became depleted (Figs $2 \& 3$ ).

With increasing light intensity from 10 to $200 \mu \mathrm{E} \mathrm{m}^{-2} \mathrm{~s}^{-1}$, the time for nitrate to be depleted (TND; $<1.5 \mu \mathrm{M}$ ) and time for the growth rate of $P$. micans to reach a lag phase (cell concentrations $>7,000$ cells $\mathrm{mL}^{-1}$ ) decreased (Figs $2 \&$ $3)$. When the initial nitrate concentrations were 100-130 $\mu \mathrm{M}$ and the initial P. micans concentrations were $\sim 1,000$ cells $\mathrm{mL}^{-1}$, the nitrate concentrations became depleted and the growth rate of $P$. micans concentrations reached a lag phase after $14 \mathrm{~d}$ at $10 \mu \mathrm{E} \mathrm{m}^{-2} \mathrm{~s}^{-1}$, but at 6-8 $\mathrm{d}$ at $100-200$ $\mu \mathrm{E} \mathrm{m}^{-2} \mathrm{~s}^{-1}$. However, in darkness, $P$. micans continuously decreased to $<100$ cells $\mathrm{mL}^{-1}$ at $18 \mathrm{~d}$ and nitrate concentrations did not clearly change. In all light intensities except for darkness, $P$. micans cells eventually reached ca. 10,000 to 12,000 cells $\mathrm{mL}^{-1}$ at the end of the experiment. With increasing light intensity, the highest growth rate of P. micans at each light intensity increased from $0.17 \mathrm{~d}^{-1}$ at $10 \mu \mathrm{E} \mathrm{m}^{-2} \mathrm{~s}^{-1}$ to $0.36 \mathrm{~d}^{-1}$ at $100 \mu \mathrm{E} \mathrm{m}^{-2} \mathrm{~s}^{-1}$, but decreased to $0.30 \mathrm{~d}^{-1}$ at $200 \mu \mathrm{E} \mathrm{m}^{-2} \mathrm{~s}^{-1}$.

When the initial nitrate concentrations were ca. 20-30 $\mu \mathrm{M}$ and initial $P$. micans concentrations were 1,000 cells $\mathrm{mL}^{-1}$ (but $\sim 500$ cells $\mathrm{mL}^{-1}$ for $200 \mu \mathrm{E} \mathrm{m}^{-2} \mathrm{~s}^{-1}$ ), the TND were $7 \mathrm{~d}$ at $10 \mu \mathrm{E} \mathrm{m}^{-2} \mathrm{~s}^{-1}$, but 3-5 d at 100-200 $\mu \mathrm{E} \mathrm{m}^{-2} \mathrm{~s}^{-1}$ (Figs 2 \& 3 ). With increasing light intensity, the highest growth rate of $P$. micans at each light intensity continuously increased from $0.19 \mathrm{~d}^{-1}$ at $10 \mu \mathrm{E} \mathrm{m}^{-2} \mathrm{~s}^{-1}$ to $0.42 \mathrm{~d}^{-1}$ at $200 \mu \mathrm{E} \mathrm{m}^{-2} \mathrm{~s}^{-1}$.

\section{Nitrate uptake rate measured using the $\mathrm{N}$ reple- tion method}

In experiment $1, P$. micans did not clearly take up nitrate in darkness (Fig. 4A). However, with increasing mean nitrate concentrations, the uptake rate of nitrate by $P$. micans at $10-100 \mu \mathrm{E} \mathrm{m}^{-2} \mathrm{~s}^{-1}$ rapidly increased at $\mathrm{NO}_{3}$ concentrations of $<20 \mu \mathrm{M}$, but slowed and then became saturated at higher $\mathrm{NO}_{3}$ concentrations (Fig. 4B-E), while at $200 \mu \mathrm{E} \mathrm{m}^{-2} \mathrm{~s}^{-1}$ it became saturated at $\mathrm{NO}_{3}$ concentrations of $<10 \mu \mathrm{M}$ (Fig. 4F).

When data were fitted to Eq. (3), with increasing light intensity from 10 to $100 \mu \mathrm{E} \mathrm{m}^{-2} \mathrm{~s}^{-1}$, the maximum uptake rate of nitrate $\left(\mathrm{V}_{\max }\right)$ by P. micans also increased from 3.6

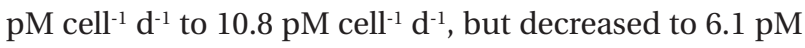
cell $^{-1} \mathrm{~d}^{-1}$ at $200 \mu \mathrm{E} \mathrm{m}^{-2} \mathrm{~s}^{-1}$ (Table 2, Fig. 4B-F). Similarly, with increasing light intensity from 10-20 to $100 \mu \mathrm{E} \mathrm{m}{ }^{-2}$ $\mathrm{s}^{-1}$, the half saturation constant for nitrate uptake $\left(\mathrm{K}_{\mathrm{s}-\mathrm{NO} 3}\right)$ increased from 4.1-4.2 to $6.9 \mu \mathrm{M}$, but decreased to $3.5 \mu \mathrm{M}$ at $200 \mu \mathrm{E} \mathrm{m}^{-2} \mathrm{~s}^{-1}$ (Table 2, Fig. 4B-F).

\section{Nitrate uptake rate measured using the $\mathrm{N}$ deple- tion method}

In experiment 2, with increasing mean nitrate concentrations, the nitrate uptake rate of $P$. micans at $20 \mu \mathrm{E} \mathrm{m}{ }^{-2}$ $\mathrm{s}^{-1}$ rapidly increased at $\mathrm{NO}_{3}$ concentrations of $<10 \mu \mathrm{M}$, but 

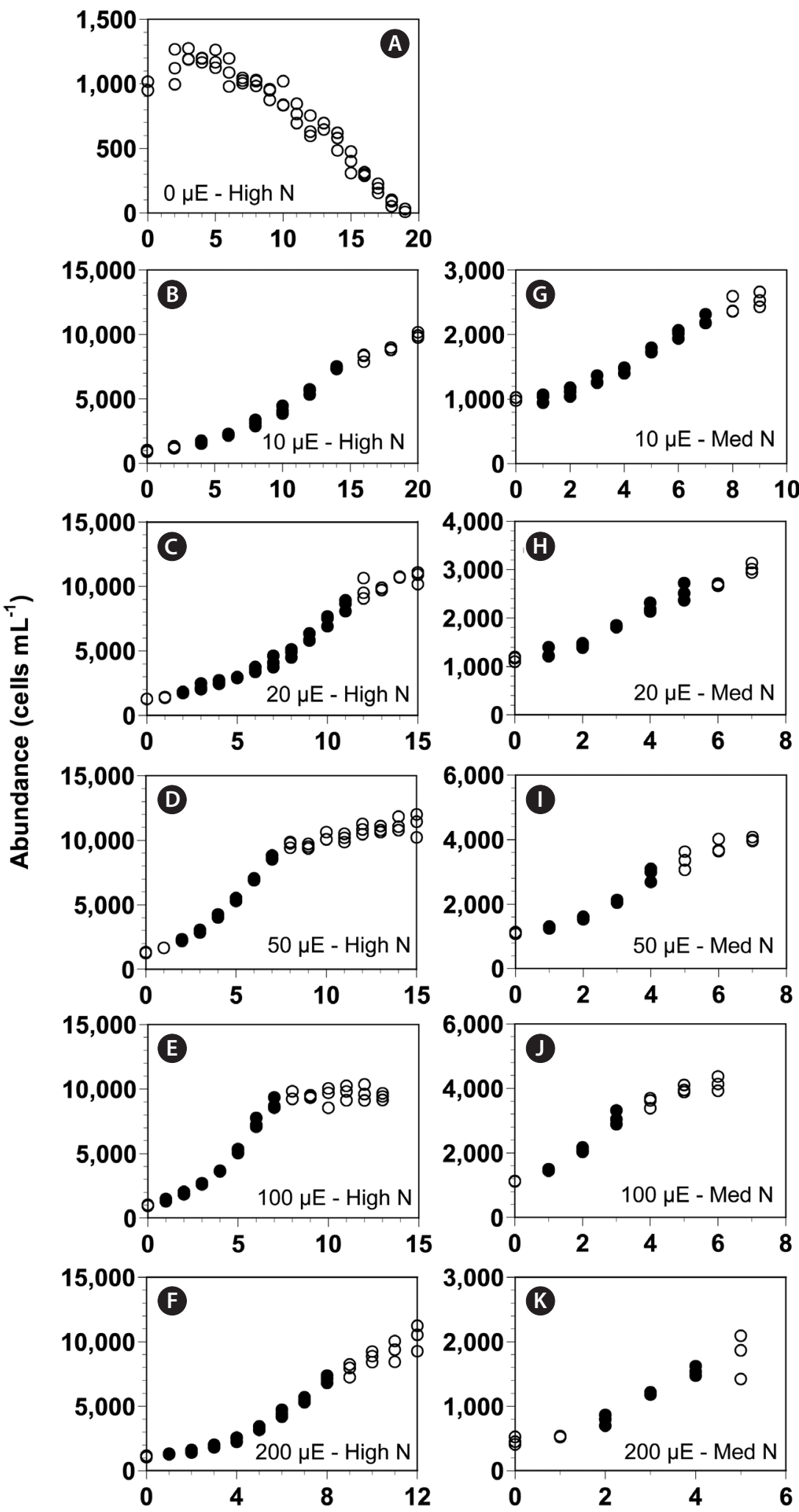

\section{Elapsed time (d)}

Fig. 2. Change in the concentration of Prorocentrum micans (cells $\mathrm{mL}^{-1}$ ) as a function of elapsed time (d) at $0,10,20,50,100$, and 200 $\mu \mathrm{E} \mathrm{m}^{-2} \mathrm{~s}^{-1}$ when high $(\mathrm{A}-\mathrm{F})$ and medium $(\mathrm{G}-\mathrm{K})$ initial $\mathrm{NO}_{3}$ concentrations were provided. Data points indicated by closed circles were used for calculating $\mathrm{NO}_{3}$ uptake and growth rates, while those indicated by the open circles were not used. 

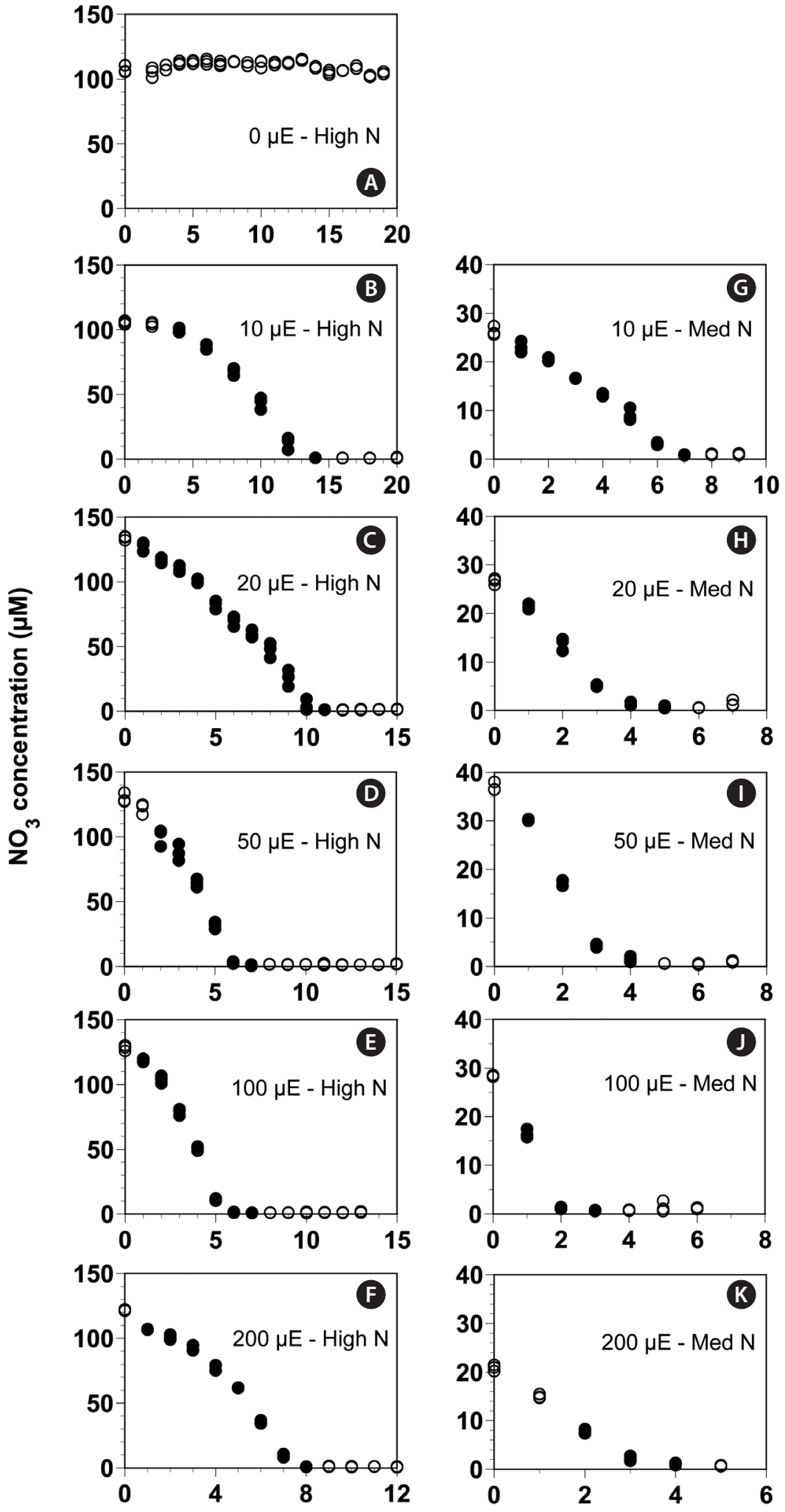

\section{Elapsed time (d)}

Fig. 3. Change in the concentration of nitrate plus nitrite $\left(\mathrm{NO}_{3}, \mu \mathrm{M}\right)$ as a function of elapsed time (d) at $0,10,20,50,100$, and $200 \mu \mathrm{E} \mathrm{m}^{-2} \mathrm{~s}^{-1}$ when high $(\mathrm{A}-\mathrm{F})$ and medium $(\mathrm{G}-\mathrm{K})$ initial $\mathrm{NO}_{3}$ concentrations were provided. Closed circles were used for calculating $\mathrm{NO}_{3}$ uptake rates, while those indicated by the open circles were not used. 


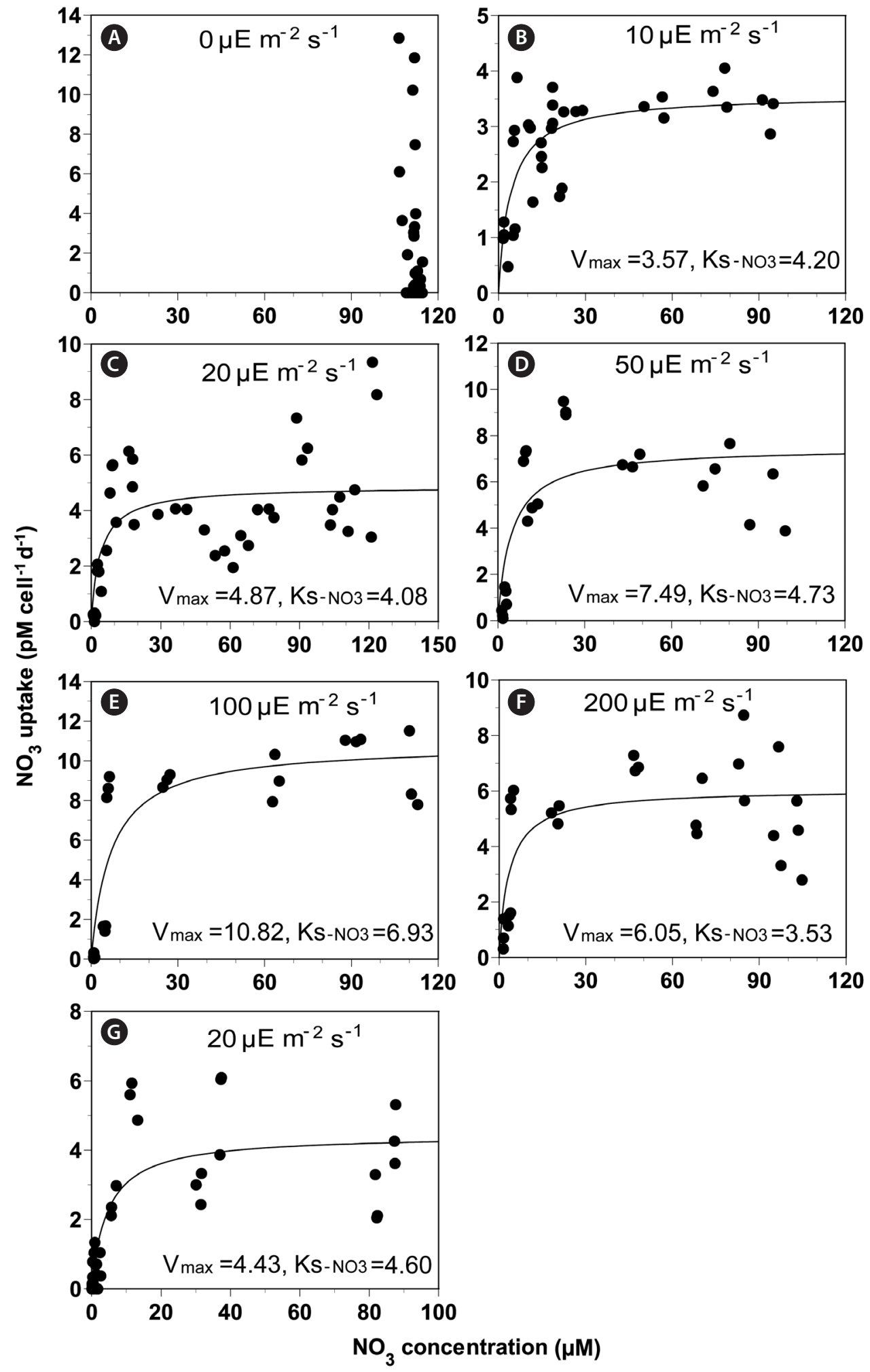

Fig. 4. Maximum $\mathrm{NO}_{3}$ uptake rates $\left(\mathrm{V}_{\max }, \mathrm{pM}\right.$ cell $\left.{ }^{-1} \mathrm{~d}^{-1}\right)$ as a function of concentrations of $\mathrm{NO}_{3}(\mu \mathrm{M}) .0,10,20,50,100$, and $200 \mu \mathrm{E} \mathrm{m} \mathrm{s}^{-1}$ using the $\mathrm{NO}_{3}$ replete $(\mathrm{A}-\mathrm{F})$ and $20 \mu \mathrm{E} \mathrm{m} \mathrm{s}^{-2} \mathrm{~s}^{-1}$ using the $\mathrm{NO}_{3}$ depleted $(\mathrm{G})$ long incubation method. The unit of the half saturation constant for uptake rates $\left(\mathrm{K}_{\mathrm{s}-\mathrm{NO} O}\right)$ is $\mu \mathrm{M}$. 


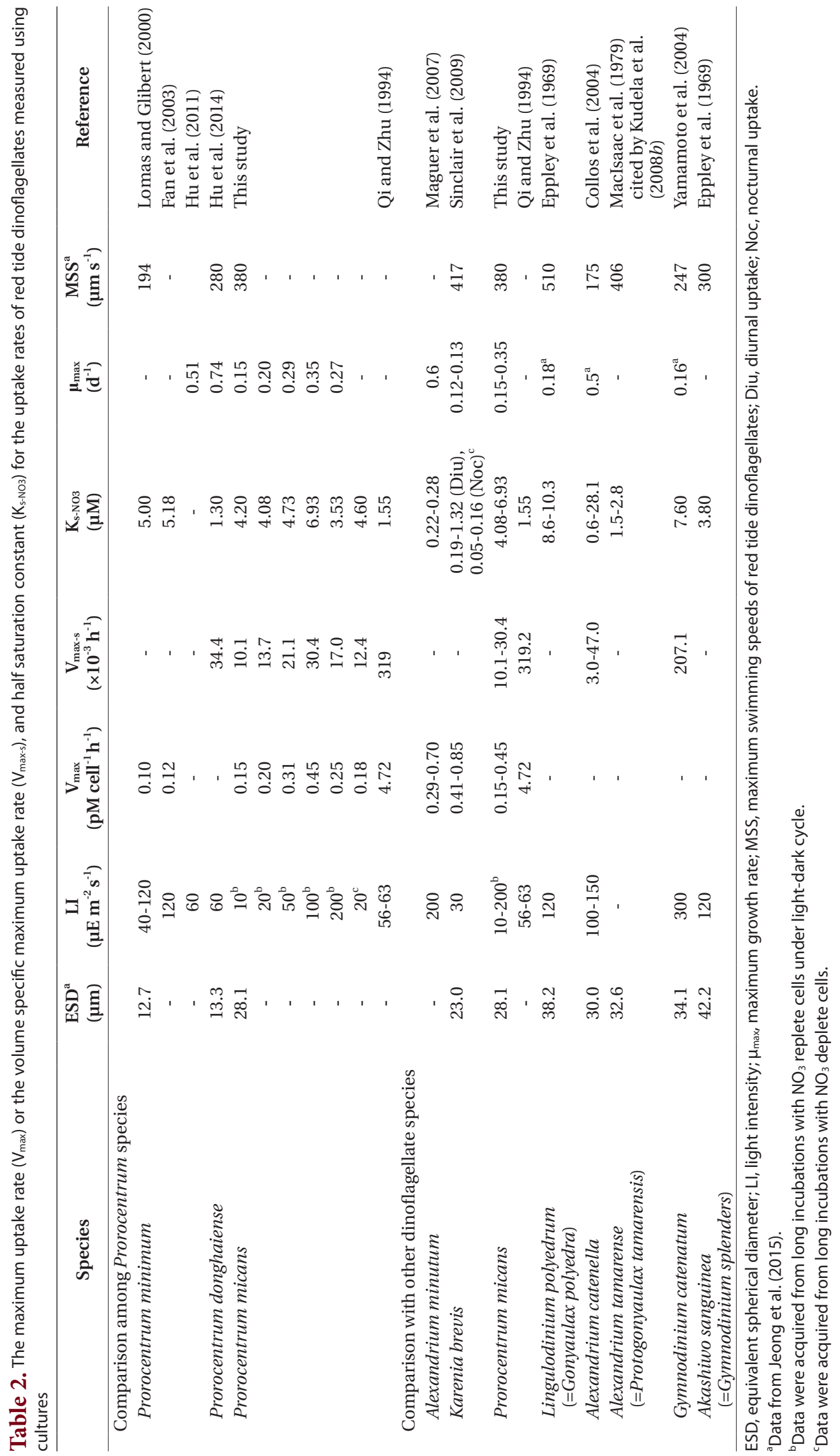



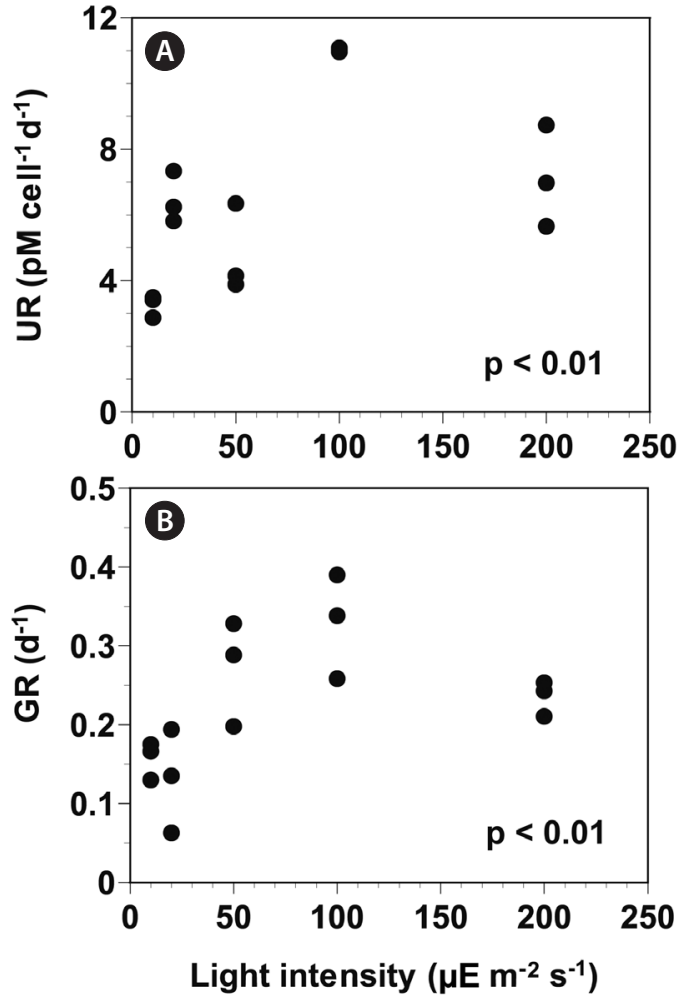

Fig. 5. Nitrate uptake rate (UR, pM cell $\left.{ }^{-1} \mathrm{~d}^{-1}\right)(A)$ and growth rate $(G R$, $\left.\mathrm{d}^{-1}\right)$ (B) of Prorocentrum micans as a function of light intensity $\left(\mu \mathrm{E} \mathrm{m} \mathrm{m}^{-2}\right.$ $\mathrm{s}^{-1}$ ) when UR and GR at each light intensity were saturated.

slowed and then became saturated at higher $\mathrm{NO}_{3}$ concentrations (Fig. 4G). When data were fitted to Eq. (3), the $V_{\max }$

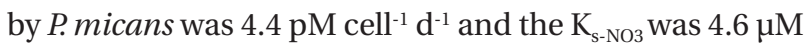
(Fig. 4G).

\section{Maximum growth rate in the $\mathrm{N}$ repletion method}

In experiment $1, P$. micans did not grow obviously in darkness. However, when data were fitted to Eq. (6), with increasing light intensity from 10 to $100 \mu \mathrm{E} \mathrm{m}^{-2} \mathrm{~s}^{-1}$, the maximum growth rate of $P$. micans also increased from 0.15 to $0.35 \mathrm{~d}^{-1}$, but decreased to $0.27 \mathrm{~d}^{-1}$ at $200 \mu \mathrm{E} \mathrm{m}^{-2} \mathrm{~s}^{-1}$ (Table 2).

\section{Effects of light intensity on the maximum nitrate uptake rate and maximum growth rate}

In experiment 1 , the nitrate uptake rates of $P$. micans at a mean $\mathrm{NO}_{3}$ concentration of $80-100 \mu \mathrm{M}$ were significantly affected by a light intensity of 10 to $200 \mu \mathrm{E} \mathrm{m}^{-2} \mathrm{~s}^{-1}$ (p $<0.01$, ANOVA) (Fig. 5A). Similarly, the maximum growth rates of $P$. micans were also significantly affected by light intensity ( $\mathrm{p}<0.01$, ANOVA) (Fig. 5B).

\section{DISCUSSION \\ Comparison of the results from the 3 different methods}

This study shows that the maximum nitrate uptake rates $\left(\mathrm{V}_{\max }\right)$ and half saturation constants for nitrate uptake $\left(\mathrm{K}_{\mathrm{s}-\mathrm{NO} 3}\right)$ of $P$. micans at $20 \mu \mathrm{E} \mathrm{m} \mathrm{m}^{-2} \mathrm{~s}^{-1}$ measured using the nutrient repletion method are similar to those measured using the nutrient depletion method. Thus, the new repletion method of measuring the nitrate uptake rate and $\mathrm{K}_{\mathrm{s}-\mathrm{NO} 3}$ using cells maintained under a nitrate repletion condition gives results similar to that using cells maintained under a nitrate depletion condition. However, the $\mathrm{V}_{\max }$ of P. micans originally maintained under nitrate repletion at $50 \mu \mathrm{E} \mathrm{m}^{-2} \mathrm{~s}^{-1}$ obtained in this study (7.49 pM cell-1 $\mathrm{d}^{-1}$, equivalent to $\left.21 \times 10^{-3} \mathrm{~h}^{-1}\right)$ is much lower than that at 56-63 $\mu \mathrm{E} \mathrm{m}^{-2} \mathrm{~s}^{-1}$ under nutrient depletion (113 pM cell- ${ }^{-1} \mathrm{~d}^{-1}$, equivalent to $319 \times 10^{-3} \mathrm{~h}^{-1}$ ) as observed by Qi and Zhu (1994), while the $\mathrm{K}_{\mathrm{s}-\mathrm{NO}}$ of P. micans originally under nitrate repletion at $50 \mu \mathrm{E} \mathrm{m}^{-2} \mathrm{~s}^{-1}$ in this study was greater than that at 56-63 $\mu \mathrm{E} \mathrm{m}^{-2} \mathrm{~s}^{-1}$. Qi and Zhu (1994) did not provide information on incubation time, light : dark cycle, and initial cell abundance, but only indicated that they used a modification of the method of Eppley (1973). Therefore, it is difficult to know the exact incubation time. However, the conventional and partially modified methods usually incubated cells for $<3 \mathrm{~h}$ without a light : dark cycle in their nitrate uptake experiments (Table 3), and thus the incubation time in the study of Qi and Zhu (1994) was likely to be shorter than that in our experiment and may not have considered the light and dark cycle. Cells maintained in a nitrate depletion condition may take up nitrate rapidly and with a short incubation time regardless of the light and dark cycle and may have a relatively high maximum uptake rate. However, the physiology and behaviors of red tide dinoflagellates, such as nutrient acquisition, cell division, and vertical migration, are known to be affected by the light and dark cycle or circadian rhythm (Suzuki and Johnson 2001, Van Dolah et al. 2007). Therefore, the nutrient depletion (long and short incubation time) method may apply to the conditions under which red tide causative cells are introduced from oligotrophic offshore surface waters to eutrophic coastal waters or when highly concentrated nutrients due to heavy rains are discharged from rivers to coastal waters after nutrient depletion conditions persist (Fig. 6A). However, this new nutrient repletion method may apply to the conditions under which nutrients are added to eutrophic waters, and high nutrient conditions in surface waters per- 


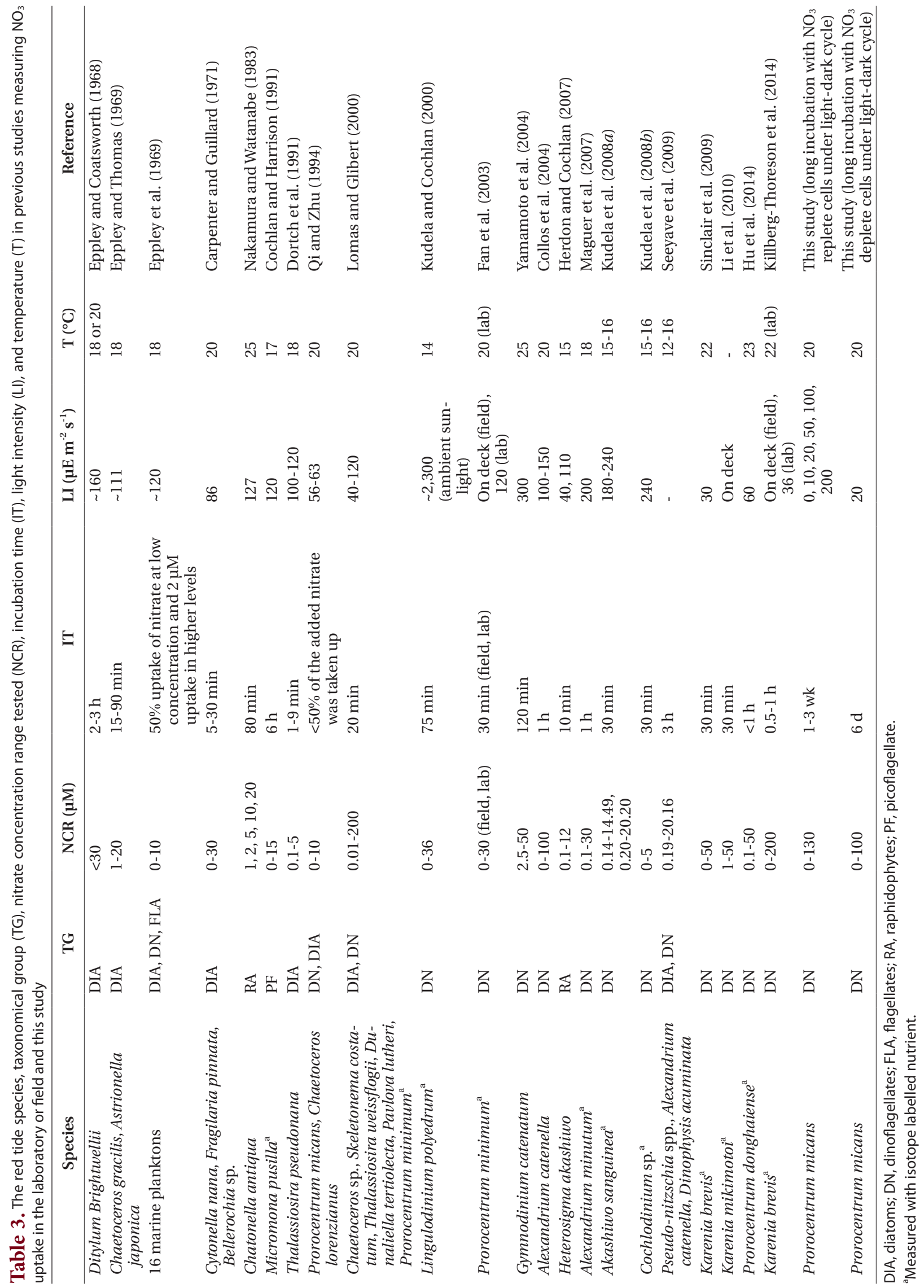




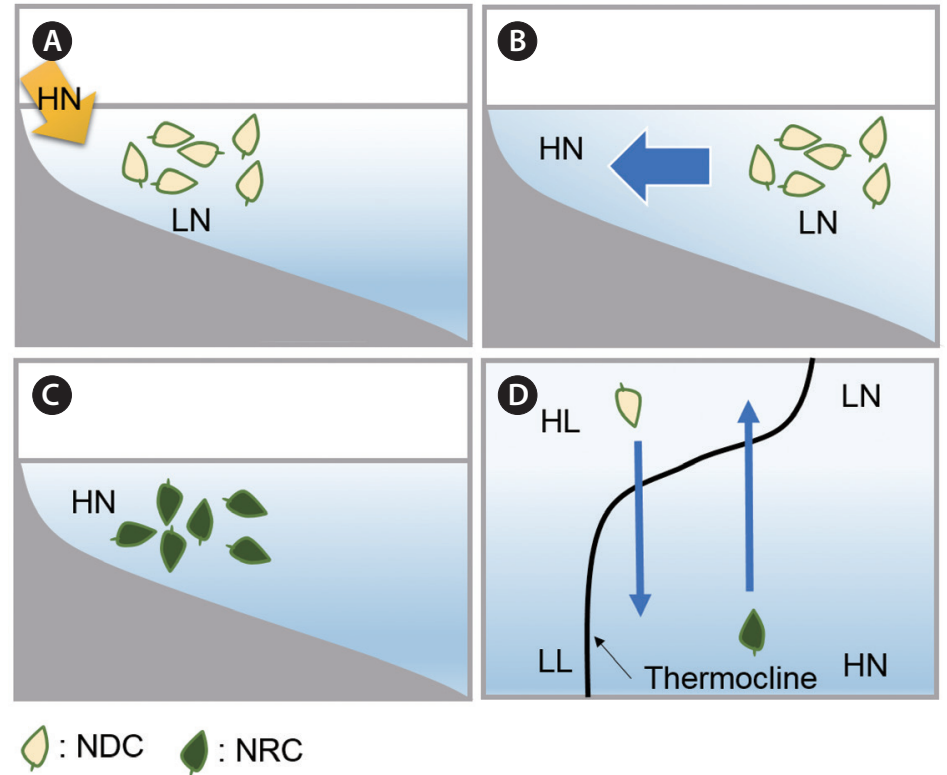

Fig. 6. Diagrams of Prorocentrum micans cells under $\mathrm{N}$ repletion and depletion conditions and then experiencing high and low nutrient waters. (A) P. micans cells experiencing high $\mathrm{N}$ after being maintained in $\mathrm{N}$ depleted waters. (B) P. micans cells are transported from $\mathrm{N}$ depleted waters offshore to $\mathrm{N}$ replete waters near the shore. (C) P. micans cells continuously maintained in N replete waters near the shore. (D) P. micans cells migrating between well-lit oligotrophic surface waters and dim eutrophicated deep waters. NDC, nitrogen depleted cell; NRC, nitrogen replete cell; $\mathrm{HN}$, high $\mathrm{N}$ concentration water; LN, low $\mathrm{N}$ concentration water; $\mathrm{HL}$, high light intensity; LL, low light intensity.

sist for a long time (Fig. 6B). In addition, this new method can be applied to red tide species that inhabit deep, but partially lit, eutrophic waters below the thermocline (Fig. $6 \mathrm{C} \& \mathrm{D})$. In natural environments, red tide species are exposed to nutrient repletion or depletion conditions, and both conditions alternate. Therefore, the results of both experiments obtained by using nutrient replete and depleted cells can be applied to certain waters where both nutrient replete and depleted conditions occur.

\section{Effects of light intensity on the maximum nitrate uptake rate and half saturation constant for nitrate uptake}

Prior to this study, there have been no studies on the effects of light intensity on the $\mathrm{K}_{\mathrm{s}-\mathrm{NO3}}$ and $\mathrm{V}_{\max }$ of nitrate of red tide organisms. Eppley et al. (1969) measured the $\mathrm{NO}_{3}$ uptake of phytoplankton with the assumption that $\mathrm{K}_{\mathrm{s}-\mathrm{NO}}$ is not influenced by irradiance. Later, most studies measured $\mathrm{NO}_{3}$ uptake at 1 light intensity. Sinclair et al. (2006, 2009) measured $\mathrm{NO}_{3}$ uptake at 2 different light intensities in each study and showed different rates between 2 light intensities. However, this study explored the effects of 6 different light intensities. The results of this study clearly show that the uptake rate of $P$. micans is affected by light intensity. The maximum swimming speed of $P$. micans is
$380 \mu \mathrm{m} \mathrm{s}^{-1}$, so it is theoretically able to descend to $14 \mathrm{~m}$ during $10 \mathrm{~h}$ of travel (Jeong et al. 2015). P. micans usually ascends at sunrise, but descends at sunset (Hasle 1950). Therefore, it is likely to experience a wide range of light intensity. Thus, it may take up nitrate at different rates at different depths when vertically migrating through the water column. In particular, the $\mathrm{NO}_{3}$ uptake rates of $P . m i$ cans at darkness were almost negligible. Therefore, it may not take up $\mathrm{NO}_{3}$ much after sunlight completely disappears from the water column.

The light intensity at which the highest $\mathrm{K}_{\mathrm{s}-\mathrm{NO} 3}$ and $\mathrm{V}_{\max }$ are achieved is the same as that at which the highest growth rate is achieved (i.e., $100 \mu \mathrm{E} \mathrm{m} \mathrm{m}^{-2} \mathrm{~s}^{-1}$ for P. micans). Thus, it is reasonable to measure the $\mathrm{K}_{\mathrm{s}-\mathrm{NO}}$ and $\mathrm{V}_{\max }$ of nitrate at the light intensity after the optimal light intensity for growth is discovered because it is generally easier to measure growth rates than nutrient uptake rates.

\section{Comparison of the maximum nitrate uptake rate and half saturation constant for the nitrate uptake of red tide dinoflagellates}

The $\mathrm{K}_{\mathrm{s}-\mathrm{NO} 3}$ of 10 red tide dinoflagellate species measured using cultures has been reported so far, and either the $V_{\max }$ or volume-specific maximum uptake rates of nitrate $\left(\mathrm{V}_{\text {max-s }}\right)$ of 7 red tide dinoflagellate species have 
been reported (Table 2). Within the genus Prorocentrum, the $\mathrm{V}_{\max }$ of the Korean strain of P. micans at $100 \mu \mathrm{E} \mathrm{m}^{-2} \mathrm{~s}^{-1}$ obtained in this study is $380 \%$ higher than that of P. minimum at a similar light intensity, but the volume specific maximum uptake rate of the Korean strain of $P$. micans was lower than that of Prorocentrum donghaiense (Table 2). The larger size of $P$. micans may be partially responsible for the higher $\mathrm{V}_{\max }$ and lower volume-specific maximum uptake rate compared to those of P. minimum and P. donghaiense. The $\mathrm{K}_{\mathrm{s}-\mathrm{NO} O 3}$ of the Korean strain of P. micans at $100 \mu \mathrm{E} \mathrm{m}^{-2} \mathrm{~s}^{-1}$ is slightly greater than that of P. minimum, but much greater than that of $P$. donghaiense (Table 2). Therefore, when nitrate concentrations are $<4 \mu \mathrm{M}, P$. donghaiense may take up nitrate and grow rapidly to form red tide patches, while P. micans may not do so. Therefore, $P$. donghaiense may inhibit $P$. micans red tide outbreaks by causing nitrate depletion or by maintaining a low nitrate concentration. However, even when nitrate concentrations are $>4 \mu \mathrm{M}$, the abundance of $P$. donghaiense is expected to be greater than that of $P$. micans because the growth rate of $P$. donghaiense is twice the maximum growth rate of $P$. micans. The maximum swimming speed of $P$. micans and, in turn, the depth it reaches through 10 $\mathrm{h}$ travel (i.e., $380 \mu \mathrm{m} \mathrm{s}^{-1}$ and $14 \mathrm{~m}$ ) are greater than those of P. donghaiense (i.e., $280 \mu \mathrm{m} \mathrm{s}^{-1}$ and $10 \mathrm{~m}$ ). Thus, P. micans is likely to outgrow $P$. donghaiense when the thermocline depth is deeper than $\sim 10 \mathrm{~m}$.

\section{Implications for red tide dynamics}

P. micans is a common red tide species in the waters of many countries (Allen 1941, Uchida 1981, Pybus 1990, Shumway 1990, Zheng-fang et al. 1995, Shankle et al. 2004, Peña-Manjarrez et al. 2005, Jeong et al. 2013, Kang et al. 2013, Park et al. 2013a); it is 1 of 3 major red tide dinoflagellates in the waters of southern California (i.e., Akashiwo sanguinea, Lingulodinium polyedrum, and $P$. micans) (Allen 1941, Cullen and Horrigan 1981, Shankle et al. 2004). It is likely to compete severally with many phototrophic species to form red tides. However, it may have difficulty in forming red tide patches in eutrophicated coastal waters due to lower growth rates, lower $\mathrm{V}_{\max }$, and higher $\mathrm{K}_{\mathrm{s}-\mathrm{NO} 3}$ than co-occurring red tide species. Its abilities to conduct mixotrophy and produce allelopathic materials over competitors may enable it to form red tides (Jeong et al. 2005, Ji et al. 2011); it is known to be able to feed on many algal prey species and inhibit the growth of the diatom Skeletonema costatum and the dinoflagellate Karenia mikimotoi using allelopathic materials (Jeong et al. 2005, Ji et al. 2011). Therefore, to understand the red tide dynamics of $P$. micans in natural environments, both $\mathrm{NO}_{3}$ uptake from ambient waters through photosynthesis and organic nitrogen through mixotrophy should be taken into consideration.

\section{ACKNOWLEDGEMENTS}

We thank Yeong Du Yoo for technical supports. This work was supported by Useful Dinoflagellate program of Korea Institute of Marine Science and Technology Promotion (KIMST), and Management of marine organisms causing ecological disturbance and harmful effect Program of KIMST, the National Research Foundation of Korea (NRF) grant funded by the Korea government (MSIP) (NRF-2015-M1A5A1041806) award to HJJ.

\section{REFERENCES}

Allen, W. E. 1941. Twenty years' statistical studies of marine plankton dinoflagellates of southern California. Am. Midl. Nat. 26:603-635.

Anderson, D. M., Alpermann, T. J., Cembella, A. D., Collos, Y., Masseret, E. \& Montresor, M. 2012. The globally distributed genus Alexandrium: multifaceted roles in marine ecosystems and impacts on human health. Harmful Algae 14:10-35.

Anderson, D. M., Glibert, P. M. \& Burkholder, J. M. 2002. Harmful algal blooms and eutrophication: nutrient sources, composition, and consequences. Estuaries 25:704-726.

Carpenter, E. J. \& Guillard, R. R. L. 1971. Intraspecific differences in nitrate half-saturation constants for three species of marine phytoplankton. Ecology 52:183-185.

Cochlan, W. P. \& Harrison, P. J. 1991. Kinetics of nitrogen (nitrate, ammonium and urea) uptake by the picoflagellate Micromonas pusilla (Prasinophyceae). J. Exp. Mar. Biol. Ecol. 153:129-141.

Collos, Y., Gagne, C., Laabir, M., Vaquer, A., Cecchi, P. \& Souchu, P. 2004. Nitrogenous nutrition of Alexandrium catenella (Dinophyceae) in cultures and in Thau laggon, Southern France. J. Phycol. 40:96-103.

Cullen, J. J. \& Horrigan, S. G. 1981. Effects of nitrate on the diurnal vertical migration, carbon to nitrogen ratio, and the photosynthetic capacity of the dinoflagellate Gymnodinium splendens. Mar. Biol. 62:81-89.

Dortch, Q., Thompson, P. A. \& Harrison, P. J. 1991. Variability in nitrate uptake kinetics in Thalassiosira pseudonana (Bacillariophyceae). J. Phycol. 27:35-39. 
Eppley, R. W. 1973. Nitrate uptake. In Stein, J. R., Hellebust, J. A. \& Craigie, J. S. (Eds.) Handbook of Phycological Methods: Physiological and Biochemical Methods. Vol. 2. Cambridge University Press, Cambridge, pp. 401-409.

Eppley, R. W. \& Coatsworth, J. L. 1968. Uptake of nitrate and nitrite by Ditylum brightwellii-kinetics and mechanisms. J. Phycol. 4:151-156.

Eppley, R. W., Rogers, J. N. \& McCarthy, J. J. 1969. Half-saturation constants for uptake of nitrate and ammonium by marine phytoplankton. Limnol. Oceanogr. 14:912-920.

Eppley, R.W. \& Thomas, W. H. 1969. Comparison of half-saturation constants for growth and nitrate uptake of marine phytoplankton. J. Phycol. 5:375-379.

Fan, C., Glibert, P. M. \& Burkholder, J. M. 2003. Characterization of the affinity for nitrogen, uptake kinetics, and environmental relationships for Prorocentrum minimum in natural blooms and laboratory cultures. Harmful Algae 2:283-299.

Fu, F. X., Tatters, A. O. \& Hutchins, D. A. 2012. Global change and the future of harmful algal blooms in the ocean. Mar. Ecol. Prog. Ser. 470:207-233.

Glibert, P. M., Burkholder, J. M. \& Kana, T. M. 2012. Recent insights about relationships between nutrient availability, forms, and stoichiometry, and the distribution, ecophysiology, and food web effects of pelagic and benthic Prorocentrum species. Harmful Algae 14:231-259.

Glibert, P. M., Icarus Allen, J., Artioli, Y., Beusen, A., Bouwman, L., Harle, J., Holmes, R. \& Holt, J. 2014. Vulnerability of coastal ecosystems to changes in harmful algal bloom distribution in response to climate change: projections based on model analysis. Glob. Chang. Biol. 20:3845-3858.

Guillard, R. R. 1975. Culture of phytoplankton for feeding marine invertebrates. In Smith, W. L. \& Chanley, M. H. (Eds.) Culture of Marine Invertebrate Animals. Springer, New York, pp. 29-60.

Guillard, R. R. L. \& Ryther, J. H. 1962. Studies of marine planktonic diatoms. I. Cyclotella nana Hustedt and Detonula confervacea (Cleve) Gran. Can. J. Microbiol. 8:229-239.

Hasle, G. R. 1950. Phototactic vertical migration in marine dinoflagellates. Oikos 2:162-175.

Herndon, J. \& Cochlan, W. P. 2007. Nitrogen utilization by the raphidophyte Heterosigma akashiwo: growth and uptake kinetics in laboratory cultures. Harmful Algae 6:260-270

Hu, H., Zhang, J. \& Chen, W. 2011. Competition of bloomforming marine phytoplankton at low nutrient concentrations. J. Environ. Sci. 23:656-663.

Hu, Z., Duan, S., Xu, N. \& Mulholland, M. R. 2014. Growth and nitrogen uptake kinetics in cultured Prorocentrum donghaiense. PLoS ONE 9:e94030.

Jeong, H. J., Lim, A. S., Franks, P. J. S., Lee, K. H., Kim, J. H., Kang, N. S., Lee, M. J., Jang, S. H., Lee, S. Y., Yoon, E. Y., Park, J. Y., Yoo, Y. D., Seong, K. A., Kwon, J. E. \& Jang, T. Y. 2015. A hierarchy of conceptual models of red-tide generation: nutrition, behavior, and biological interactions. Harmful Algae 47:97-115.

Jeong, H. J., Yoo, Y. D., Lee, K. H., Kim, T. H., Seong, K. A., Kang, N. S., Lee, S. Y., Kim, J. S., Kim, S. \& Yih, W. H. 2013. Red tides in Masan Bay, Korea in 2004-2005: I. Daily variations in the abundance of red-tide organisms and environmental factors. Harmful Algae 30(Suppl. 1):S75-S88.

Jeong, H. J., Yoo, Y. D., Park, J. Y., Song, J. Y., Kim, S. T., Lee, S. H., Kim, K. Y. \& Yih, W. H. 2005. Feeding by the phototrophic red-tide dinoflagellates: five species newly revealed and six species previously known to be mixotrophic. Aquat. Microb. Ecol. 40:133-155.

Ji, R. \& Franks, P. J. 2007. Vertical migration of dinoflagellates: model analysis of strategies, growth, and vertical distribution patterns. Mar. Ecol. Prog. Ser. 344:49-61.

Ji, X., Han, X., Zheng, L., Yang, B., Yu, Z. \& Zou, J. 2011. Allelopathic interactions between Prorocentrum micans and Skeletonema costatum or Karenia mikimotoi in laboratory cultures. Chin. J. Oceanol. Limnol. 29:840-848.

Kang, N. S., Lee, K. H., Jeong, H. J., Yoo, Y. D., Seong, K. A., Potvin, É., Hwang, Y. J. \& Yoon, E. Y. 2013. Red tides in Shiwha Bay, western Korea: a huge dike and tidal power plant established in a semi-enclosed embayment system. Harmful Algae 30(Suppl. 1):S114-S130.

Killberg-Thoreson, L., Mulholland, M. R., Heil, C. A., Sanderson, M. P., O’Neil, J. M. \& Bronk, D. A. 2014. Nitrogen uptake kinetics in field populations and cultured strains of Karenia brevis. Harmful Algae 38:73-85.

Kudela, R. M. \& Cochlan, W. P. 2000. Nitrogen and carbon uptake kinetics and the influence of irradiance for a red tide bloom off southern California. Aquat. Microb. Ecol. 21:31-47.

Kudela, R. M., Lane, J. Q. \& Cochlan, W. P. 2008a. The potential role of anthropogenically derived nitrogen in the growth of harmful algae in California, USA. Harmful Algae 8:103-110.

Kudela, R. M., Ryan, J. P., Blakely, M. D., Lane, J. Q. \& Peterson, T. D. 2008b. Linking the physiology and ecology of Cochlodinium to better understand harmful algal bloom events: a comparative approach. Harmful Algae 7:278-292.

Kudela, R. M., Seeyave, S. \& Cochlan, W. P. 2010. The role of nutrients in regulation and promotion of harmful algal blooms in upwelling systems. Prog. Oceanogr. 85:122135. 
Lee, K. H., Jeong, H. J., Kwon, J. E., Kang, H. C., Kim, J. H., Jang, S. H., Park, J. Y., Yoon, E. Y. \& Kim, J. S. 2016. Mixotrophic ability of the phototrophic dinoflagellates Alexandrium andersonii, A. affine, and A. fraterculus. Harmful Algae 59:67-81.

Li, J., Glibert, P. M. \& Zhou, M. 2010. Temporal and spatial variability in nitrogen uptake kinetics during harmful dinoflagellate blooms in the East China Sea. Harmful Algae 9:531-539.

Lim, A. S., Jeong, H. J., Jang, T. Y., Jang, S. H. \& Franks, P. J. S. 2014. Inhibition of growth rate and swimming speed of the harmful dinoflagellate Cochlodinium polykrikoides by diatoms: implications for red tide formation. Harmful Algae 37:53-61.

Lomas, M. W. \& Glibert, P. M. 2000. Comparisons of nitrate uptake, storage, and reduction in marine diatoms and flagellates. J. Phycol. 36:903-913.

MacIsaac, J. J., Grunseich, G. S., Glober, H. E. \&Yentsch, C. M. 1979. Light and nutrient limitation in Gonyaulax excavata: nitrogen and carbon trace results. In Taylor, D. L. \& Selige, H. H. (Eds.) Toxic Dinoflagellate Blooms. Elsevier, New York, pp. 107-110.

Maguer, J. -F., L'Helguen, S., Madec, C., Labry, C. \& Le Corre, P. 2007. Nitrogen uptake and assimilation kinetics in $\mathrm{Al}$ exandrium minutum (Dynophyceae): effect of N-limited growth rate on nitrate and ammonium interactions. J. Phycol. 43:295-303.

Nakamura, Y. \& Watanabe, M. M. 1983. Nitrate and phosphate uptake kinetics of Chattonella antiqua grown in light/dark cycles. J. Oceanogr. Soc. Jpn. 39:167-170.

Park, J., Jeong, H. J., Yoo, Y. D. \& Yoon, E. Y. 2013a. Mixotrophic dinoflagellate red tides in Korean waters: distribution and ecophysiology. Harmful Algae 30(Suppl. 1):S28-S40.

Park, T. G., Lim, W. A., Park, Y. T., Lee, C. K. \& Jeong, H. J. $2013 b$. Economic impact, management and mitigation of red tides in Korea. Harmful Algae 30(Suppl. 1):S131-S143.

Peña-Manjarrez, J. L., Helenes, J., Gaxiola-Castro, G. \& Orellana-Cepeda, E. 2005. Dinoflagellate cysts and bloom events at Todos Santos Bay, Baja California, México, 1999-2000. Cont. Shelf Res. 25:1375-1393.

Pybus, C. 1990. Blooms of Prorocentrum micans (Dinophyta) in the Galway Bay area. J. Mar. Biol. Assoc. U. K. 70:697705 .

Qi, Y. Z. \& Zhu, C. J. 1994. A comparative study of nitrate up- take kinetics by two red tide causative algae. Asian Mar. Biol. 11:103-106.

Seeyave, S., Probyn, T. A., Pitcher, G. C., Lucas, M. I. \& Purdie, D. A. 2009. Nitrogen nutrition in assemblages dominated by Pseudo-nitzschia spp., Alexandrium catenella and Dinophysis acuminata off the west coast of South Africa. Mar. Ecol. Prog. Ser. 379:91-107.

Sinclair, G., Kamykowski, D. \& Glibert, P. M. 2009. Growth, uptake, and assimilation of ammonium, nitrate, and urea, by three strains of Karenia brevis grown under low light. Harmful Algae 8:770-780.

Sinclair, G. A., Kamykowski, D., Milligan, E. \& Schaeffer, B. 2006. Nitrate uptake by Karenia brevis. I. Influences of prior environmental exposure and biochemical state on diel uptake of nitrate. Mar. Ecol. Prog. Ser. 328:117-124.

Shankle, A. M., Mayali, X. \& Franks, P. J. S. 2004. Temporal patterns in population genetic diversity of Prorocentrum micans (Dinophyceae). J. Phycol. 40:239-247.

Shumway, S. E. 1990. A review of the effects of algal blooms on shellfish and aquaculture. J. World Aquac. Soc. 21:65104.

Smayda, T. J. 1997. Harmful algal blooms: their ecophysiology and general relevance to phytoplankton blooms in the sea. Limnol. Oceanogr. 42:1137-1153.

Suzuki, L. \& Johnson, C. H. 2001. Algae know the time of day: circadian and photoperiodic programs. J. Phycol. 37:933-942.

Uchida, T. 1981. The relationships between Prorocentrum micans-growth and its ecological environment. Sci. Pap. Inst. Algol. Res. Fac. Sci. Hokkaido Univ. 7:17-76.

Van Dolah, F. M., Lidie, K. B., Morey, J. S., Brunelle, S. A., Ryan, J. C., Monroe, E. A. \& Haynes, B. L. 2007. Microarray analysis of diurnal- and circadian-regulated genes in the Florida red-tide dinoflagellate Karenia brevis (Dinophyceae). J. Phycol. 43:741-752.

Yamamoto, T., Oh, S. J. \& Kataoka, Y. 2004. Growth and uptake kinetics for nitrate, ammonium and phosphate by the toxic dinoflagellate Gymnodinium catenatum isolated from Hiroshima Bay, Japan. Fish. Sci. 70:108-115.

Zheng-fang, W., Qing, Z. \& Min, G. 1995. The effects of nitrogen, phosphorus, vitamins and trace metals on the growth of the red tide organism Prorocentrum micans. Chin. J. Oceanol. Limnol. 13:338-342. 